\title{
Reconstructing the Present through the Past: Remedying Social Services Delivery Failure among the Yorubas of Nigeria
}

\author{
Adeleke Adegbami (Corresponding author) \\ Department of Public Administration, \\ Obafemi Awolowo University, Ile-Ife. \\ e-mail: adeadegbami@yahoo.com Tel: 08034056781 \\ Oluwasesan Nofiu \\ Department of Public Administration, \\ Oduduwa University, Ipetumodu, Ile-Ife. \\ e-mail: o.nofiu@yahoo.com \\ Tel: 07059943353
}

Received: August 02, 2013 Accepted: August 18, $2013 \quad$ DOI: 10.5296/jpag.v3i3.4381

\begin{abstract}
The pre-colonial Yoruba nation had well organized political and administrative structures which were truncated by the 19thc British occupation of the territory. By 1960, Nigeria got her independence with full expectations that the new government will usher in developments especially in the area of social service delivery and contrary to the expectations, the hopes were dashed. The paper examines the collective action approach which the Yoruba nation adopted to tackle the problems of social services delivery failure. The paper concludes that for efficient and effective delivery of services, it is necessary to establish an effective mutual link between the leaders and the led.
\end{abstract}

Keywords: Reconstructing, Remedying, Social Services Delivery, Alternative Community Development Efforts, Good Governance, Yoruba Nation 


\section{Introduction}

History had it that organized state structures existed in each of the diverse ethnic groups of Nigeria several years before the occupation of her territory by the European imperialists. The 19th century was a very important epoch in the history of Nigeria nation; the period marked a turning point in the socio-cultural, economic and political life of the people in Nigeria. The 1954 Constitution known as Lyttelton Constitution marked the inauguration of Nigeria Federation comprising three Regions with a measure of autonomy at the Regional level. By 1960, Nigeria got her independence from the British imperialist as a federal nation. At independence, expectations of the people were high that the new government will usher in progress and developments especially in the area of social service delivery and good governance, contrarily, few years after, all these expectations were dashed. This was because; the Nigerians political leaders were distracted from meeting the yearning and aspirations of the people as they focused on 'operation clamp down oppositions'. The Political leaders made every available means to subjugate all forms of opposition to their government such that all perceived opposition leaders were sentenced to jail time. This was particularly the case in the first Republic. The post-independence political development in Nigeria was therefore 'monocratically centralized in nature' as it separated political leaders from their subjects (Akinola, 2006). The relationship that existed between the state and the citizens was that of separation and exclusion contrary to the pre-colonial period where people worked together to build their community.

The expectation that state can resolve all the social problems was dashed as the events unfold in the post-independence period just as the formal structure of government in Nigeria become a fiction in governance. Olowu and Erero (1997) aptly captured the scenario when they posit that the services that Nigerian government provided have declined sharply both in quality and quantity, this has given rise to the development of alternative institutional structures for providing essential services. The inability of the state to tackle the problems of social service delivery in different parts of the nation led to the embracement of self-governing system by the people through alternative effort and collective action. The role of infrastructural facilities in development and poverty reduction cannot be over emphasized be it in urban or rural environments. Therefore, the paper set to examine the role of Nigerian citizens at providing service delivery which government has failed to do in their community through joint effort.

\section{Review of Literature}

Social services delivery or infrastructural facilities are indispensable to the welfare of people in any part of the globe. In most of the developing countries of the World, the provision of social services is the responsibility of the government, along the line however, the government failed in the adequate provision of these amenities. This has led to the involvement of citizens in the provision of these valuable amenities.

The concept of social service delivery according to Oyedele (2012), Nnamani and Chilaka (2012) are services provided by the government and its agencies for the welfare of the citizens. The essence of social services delivery is for the welfare and benefits of the people as without these facilities, there will be no meaningful living. These services include housing, 
health care delivery, good roads, housing, portable water, toilet facilities and electricity. All these infrastructures are for the betterment of the people in the society.

Continually there is a growing demand for social services delivery. This has thus, generated the question of how these services could be constantly provided, funded and delivered to the citizens. This is because the resource constraints do undermine the provision of social services. For instance, resource constraints in Nigeria do come as a result of endemic corruption which had eaten deep into the fabrics of the nation. Since provision of infrastructural facilities could only be achieved through good governance, Nigeria's infrastructural development accordingly, has been disgustingly hindered by the high level of corruption among the nation bureaucrats and political leaders (Anazodo, Okoye and Ezenwile, 2012). Anazodo et al., (2012:124) further assert thus

This monumental corrupt practice in Nigeria is very severe and devastating. The menace of corruption by Nigerian leaders has certainly emerged as one of the main impediments to national development. Corruption by Nigerian leaders has caused the country severe losses economically, politically and socially, and these facts are responsible for decayed infrastructure...

In his study, Akinwale (2010) argues that two-third of the Nigerian children have no access to immunization which is one of the social services; the women also, do not have access to good health service delivery, this consequently had led to an increase in maternal mortality in Nigeria. Furthermore, electricity provision which is inadequate has hampered the economic development of the people as well as their social lives.

In his study titled Community-led Infrastructure Provision in Low-Income Urban Communities in Developing Countries: A study on Ohafia, Nigeria, Eziyi (2009) asserts that one of the important problems facing developing countries is inadequate housing and infrastructural facilities for the citizenry. Eziyi while citing World Bank (2003), and other scholars equally highlights factors responsible for poor infrastructural facilities in developing countries, which, include persistent 'economic and political crises', 'ineffective infrastructural delivery systems', and 'bad governance'.

On the effect of inadequate social service delivery, Oguzor (2011) argues that the inadequate provision of social services delivery such as electricity supply, portable water, health care services, transportation and communication hinder better condition of living of the citizens. Thus, ineffective and inadequate social services delivery is tantamount to social failure which is detrimental to people successful living.

\section{Decentralized and Local Governance as panacea to Poor Service Delivery}

By decentralization, we mean the transfer of authority and responsibility from central to intermediate and local governments. Decentralized governance is aimed to address failure of the centralized governance in order to foster socio-political development which will consequently reduce poverty, as well as consolidate democracy. Scholars particularly from African background have advocated decentralization due to the advantages attached to it 
which include: enhancing government-citizens participation and increased resource mobilization for development projects as well as a tool to achieve better governance. In spite of these laudable advantages attached to decentralization, it is regrettable that in most African states when government announced decentralization, there is no distinct evidence of decentralization as the central government still wields powers and controls all governmental activities (Wunsch and Olowu, 1990).

In practice, decentralization is perceived in different way from one nation to the other and as a result its impact depends on the rationale behind the adoption and method of its implementation as provided for in the nation's constitution. However, in order to guarantee efficiency and effectiveness in the institutional arrangements, sustained political will is essential (Department for International Development, 2002). Therefore, for effective decentralization, there must be checks and balances among the component parts of the nation in term of exercised power.

In tune with decentralization is 'local governance'. Various scholars have given their views concerning the concept of local governance. For instance, Ostrom (1990) and Olowu,Wunsch and Ayee (2004) see local governance as a rule-governed process through which residents of a defined area participate in governance of their area in limited but locally important matters. These residents are the key decision-makers, they know what their needs are. They equally come together and generate resources to provide the amenities needed. Mukoro (2009) sees governance as the way society as a whole manages the full array of its political, economic and social affairs. That is, governance involves power relationship between 'formal government institutions' and local self-communities. Thus, for the communities to experience a better life, they need to participate in the management of their own affairs by articulating their interests, exercising their legal rights, and meeting their obligations.

\section{Pre-Colonial Nigeria: A Yardstick for Good Governance}

The period of colonial rule in Nigeria beginning from 1885 when Berlin West African Conference which partitioned African country among European imperialists was held to about 1951 saw Nigeria disconnected from her 'root'. This is to say that the system of administration that was introduced by the British during the Colonial period and adopted by successive post-colonial Nigerians leader shifted the indigenous mode of administration to the British system of administration. This system of administration destroyed the basic indigenous Administrative System that was practiced by different ethnic groups in the present day Nigeria such as Yoruba, Igbo and Hausa/Fulani. The colonial administration in Nigeria had a far reaching effect and impact on Nigeria's political, economic, constitutional, social, agricultural and technological development. Significantly, the indigenous socio-political structure among the Yoruba provided a workable arrangement before the advent of colonial rule

4.1 Political System: It is an indisputable fact of history that Nigeria is a British creation. This is to say that different ethnic groups of Nigeria were brought together politically by the British imperialist. Prior to the British occupation of Nigeria, the Yorubas, the Igbos and the Hausa-Fulanis had evolved their peculiar political institutions. For example in Yoruba nation, 
there has always been a balance of power between the paramount rulers (Obas) and the Chiefs (Oloyes), also, there are other societies leaders who act as checks on the paramount rulers for instance the 'Cult' (known as Ogboni societies which elders in the town belong to). These set of elders could express the people's displeasure against the rulers. Due to these checks and balances, the Yoruba political-administrative structure has been effectively stable. These acceptable means of governance were unfortunately eroded by the colonial rulers as well as post-independence leaders, thus the paramount rulers could now be seen as ceremonial figure that have been stripped of political and administrative power. Thus, the government which relates and interacts freely with her subjects was schemed out political and administrative positions.

4.2 Constitutions: Pre-colonial constitution of Yoruba was unwritten, but the elders, family head, community head, chiefs, King and the subjects within the community or town were aware of the do's and don'ts in their different environment and they adhered strictly to these rules and regulation as applied. The subjects then were obedient to law; crimes were to its barest minimum and nobody was above the law. But nowadays things have changed.

4.3 Agriculture and Technology: In the Pre-colonial Yoruba nation, the major means of economy sustenance was agriculture. Then citizens embarked on mass food production. Others engaged in hunting of animals and in rearing animals. While some engaged in trading. Technologically, Yoruba people practised blacksmithing. They made farms implement like cutlass, hoes and tools for hunting. The Yorubas were not push over in economic activities. With the coming of Europeans, their productions and produce changed toward the needs of the European, that is, the Yorubas planted to satisfy the European wants than their wants. In the colonial era, Yoruba like other nations in Africa concentrated almost entirely on export of raw cotton and the import of manufactured cotton cloth. This remarkable reversal is tied to technological advance in Europe and to stagnation of technology in Yoruba nation as well as other nations of Africa (Rodney, 1972). The final blow to agricultural practices was the discovery of the crude oil in Nigeria. This made a lot of Yoruba citizens and other Nigerian citizens to leave agriculture for other 'neat' jobs. The consequence of which is food shortage which made Yoruba and Nigeria at large become a major food importer in order to feed its citizens.

4.4 Educational System: With the coming of the European rulers, the Yoruba system of Education was adulterated as it deviated from peoples 'roots' and culture. Akinola (2006) argues that

Nigeria elite are alienated in terms of educational curriculum adopted by the British Government which Nigerian leaders continue till date. The curriculum did not pay much attention to the study of Nigeria culture, its roots and adaptive education that can help the society to realize the potentials and capabilities of the Nigerian people. This problem still persists till today as higher institutions in the country only train students for white collar jobs instead of creating jobs using local resources (Akinola, 2006:7). 


\section{Macrothink}

The rich Yoruba education which was suitable and appropriate for her people had being supplanted and destroyed. Pre-colonial Yorubas system of education was people centered, people oriented and complete in areas of cognitive, affective, psychomotor domain. The indigenous education was perfect and outstanding as it has close links with social life, both in a material and spiritual sense, it makes child to be familiar with the nature and natural environments, and it entails progressive development of child in conformity with the successive stages of physical, emotional and mental development (Rodney, 1972). For instance, in Yoruba nation, Children of age eight could name ten to twenty different kinds of crops and plants especially the one they plant in their farms and out of which they ate, but they knew next to nothing about ornament flowers, this is because flower is not of importance to their environment.

Similarly, in the Yoruba part of Nigeria, there existed school of history, the teacher (elder) would drill into memories of the pupils (children) a long list of kings who have ruled and reign in the land, the period which they ruled and their achievements, the pupils were also drilled in reciting the lineage praises (Oriki Orile) and be able to say about their fore-fathers within the clan. Also, folklores (Alo) were thought to the children, and basic importance of folktales is that it is used to inculcate moral training into the children. The educational advancement in Yoruba then brought about more specializations in the areas of iron working, leather making, cloth manufacture, pottery moulding, professional trading, these were the types of the education then compared to post-independence educational system where students only look for white collar jobs instead of applying knowledge acquired to create jobs using local materials.

\subsection{Administrative, Judiciary and Security System}

\subsubsection{Administrative System}

The administrative system of pre-colonial Yoruba was centered around the King (Oba) and the Council of Elder (Ijoye), but the Oba remained the overall head. They were in-charge of conceiving, planning implementing and managing the community's development projects, such as: building public infrastructure, King's palace, markets and general maintenance of all the projects within the town.

The Chief Priests (Olu-awo) in the Yoruba part of Nigeria were the people who were endowed with spiritual powers. The Chief priest's positions were more often inherited than learnt. They acted as the link between members of the community and their ancestors. The Chief priests were saddled with the responsibilities of educating the community in traditional/spiritual laws, religious doctrines and principles. They also provided information to the people on the importance of living in harmony with the natural environment, such as: land, rivers, and forests, and that member of the community must see themselves simply as custodians and not owners of these natural resources. In addition, the Chief Priests were health officials in that they were responsible for healing the sick and recommended appropriate herbs for different types of sicknesses in addition to doing midwifery jobs.

\subsubsection{Judicial System}

In judicial matter, the king and his chief were the Chief Judge. They presided over different 
cases between and among citizens. When an offence is committed, the offender is brought to king's court where he or she is allowed to state his or her own side of story and based on this, judgment will be passed and subsequent punishment will be meted on the offender. The offender could at times be banished from town or even killed depending on the offence(s) committed.

\subsubsection{Security System}

The communities were protected by the Balogun (the Chief warlord) and his team of army usually comprising strong and energetic people from the community who relied heavily on both physical strength and magical power. In some communities, they were being protected by the Olori-Ode (Head of Hunters) and his fellow hunters. They were very loyal and always ensured that the community people's lives and properties were safe.

\section{Corruption: Implication for Social Service Delivery in Nigeria}

What is paramount to most of Nigerian political and administrative leaders at all levels of government nowadays is how to loot and share money. Gone are the days when honesty, integrity and transparency have meaning in Nigeria. This was the time when there were progressive minded people at the helms of affairs of the country. For instance people like Obafemi Awolowo, the Prime Minister of the then Western Region of Nigeria. Awolowo will never be forgotten in the history of Nigeria for being a leader with proven records of achievement. The cases of corruption in Nigeria nowadays include: slow movement of files in offices, ghost workers syndrome, and inflation of contract fund, diversion of public fund, police extortions, election irregularities, examination malpractices and certificate forgery among others. Corruption cuts across faiths, religious denomination and political affiliation. No wonder that as published by Transparency International (TI) out of 179 most corrupt countries all over the world, Nigeria is number 121!(Nigeria Tribune, $10^{\text {th }}$ June, 2010). All these were absent in pre-colonial Nigeria, but now it has been institutionalised and this has caused and still causing serious damages to the polity.

\section{Regionalism: Lesson from Obafemi Awolowo Effective Service Delivery in Yoruba Nation, South-Western Nigeria}

The period of regional governance in Southwestern Nigeria witnessed tremendous development due to the vision of the then premier. The region that was most outstanding among the then three Regions (Northern, Eastern and Western) was the Western region, premiered by Chief Obafemi Awolowo. He became the first Premier of the former Western Region in 1954. During his tenure of office as the Premier of Western Region from 1954 to 1959, his achievements were so outstanding that the region became the first among its equal in terms of good governance and development in Nigeria. Awolowo was able to put into practice some of his social and political doctrines, by these doctrine, the Western region was able to manage its resources which was mainly derived from cocoa plantations so well that she was able to give free medical services for all in 1953, minimum wage for workers in 1954 for the first time in the history of Nigeria. Also, Western Region was the first to introduce free Universal Primary Education (UPE) in 1955. Other outstanding developmental achievements of the Western region government include the launching of the first Television Station in 
Africa at Ibadan in 1954, the building of a standard Stadium known as Liberty Stadium at Ibadan in Nigeria (now Obafemi Awolowo Stadium) and in 1962, the University of Ife (now Obafemi Awolowo University), was founded under the Western Regional Government.

\section{Individual and Collective Effort at Developing the Community}

Individual and collective effort at developing their community cannot be overemphasized. In Yoruba nation today, individual as well as collection of people have tremendously assisted in developing their community. People in the community who shared the same view do come together in a bid to provide such amenities that Government failed to provide. While some cliques at the helms of affair are busy sharing the national wealth these outstanding classes of individuals and collection of people are using their own resources to provide social amenities to their community. While the few leaders and the state institutions are characterized by corruption, majority of Nigerians have learnt not to rely on government but rather to look inward and embark on the provisions of essential services that government has failed to produce (Akinola, 2006). Individuals have contributed immensely to the development of their towns in Yoruba nation, for example, the Late Oba Oladele Olashore, the Aloko of Iloko Ijesa, had assisted his town in the area of educational development by building two standard secondary schools. In addition to these, he built a world-class hotel and bakery industry where people work daily to earn their living.

Similarly, the Late Chief Lawrence Omole in Ilesa, another town in Yoruba nation, contributed immensely toward the development of his town. During his life time he was reputed to have contributed to the expansion of Osun State College of Education, Ilesa, where he built a standard Library for the college as well as other beautiful structures. In Okeigbo, a relatively small town in Yoruba nation, Professor Dele Olowu, has also assisted his hometown by constructing new classrooms and renovate the dilapidated ones as well as equipping the science laboratory for the use of the students.

Community institutions possess self-organizing capabilities through which community members relate with one another in a rule-ordered relationship, sharing ideas and using their own initiative and institutional potentials to address problems of daily existence (Akinola, 2007). In many quarters in Ile-Ife, records have it that people worked together to develop their quarter in many areas. People contribute to construct roads, buy transformers to generate electricity, install electrical poles and other electricity-generating materials just to help the community. Also, it is no news again that people provide for their own security in most communities in Ile-Ife. They hire night guards and pay through their contributions. Also, they organize themselves into vigilante groups to protect the lives and properties of the people in their community.

The role of indigenous structures of governance cannot be overemphasized as it exists in different communities across Nigeria where people come together in order to proffer solution to their social amenities problems. Community Development Associations (CDAs) as witnessed in Yoruba nation are of immense value to the development of communities. These are the associations based on trust and harmonious relationship with the intention of meeting the welfare need in term of social amenities which the government had failed to provide. 


\section{Mll Macrothink}

Journal of Public Administration and Governance ISSN 2161-7104 2013, Vol. 3, No. 3

These Community Developments Associations (CDA's) which could be found in all parts of Yoruba nation source funds through contributions, special levies, donations from well wishers and annual launching and this has been their sustaining power. The spirit of 'working together' a sort of rotational labour which is known as aaro in the Yoruba culture and tradition has always been their motivating factor. Working together for the community has been part of Yoruba life and this has gone a long way to help them. However, inadequate funds has always constitute a limiting factors to the extent to which they could go regarding the provision of social services, that notwithstanding, CDA's have contributed immensely to the development of social services delivery in different parts of Yoruba nation.

\section{Alternative Effort to Poor Service Delivery through Community Participation}

There is no disputing fact that the Government at the Centre has failed in its duty to provide necessary infrastructural facilities for the people of Nigeria. Government has failed so also have public officers. Former President of Nigeria, Chief Olusegun Obasanjo even admitted this while he was still in office. According to him

Nigerians have for too long been feeling short-changed by the quality of public services delivery...Our public offices have too long been showcases for the combined evils of inefficiency and corruption, whilst being impediments to effective implementation of government policies. Nigerians deserve better. (Obasanjo cited in FGN, 2007:1).

If the number one citizen of Nigeria as at that time could say this concerning public services delivery, it means the 'lesser citizens' should find 'next available solution' to tackle problems of social and infrastructural deficiency before it is too late. The solution where by citizens are able to organise multiple governing authorities, as well as private arrangements, on different scales (Ostrom and Ostrom, 2003, cited in Akinola, 2006), such that 'each centre acts in ways that take account of others and such a system relies on the self-capabilities of each unit and funds unity in their interdependence' (Akinola, 2006). By this alternative solution, the affairs of the local community will be controlled by the people themselves. People will have a say in their own affairs and since they are thorough bred local people they know where their shoe is pinching in term of infrastructural amenities, consequently they will be able to tackle it. Besides when people participate in the governance of the communities and contribute resources for social services, the issue of corruption will be minimized hence development of their communities will be rapid.

The issue of uniformity in governance should be discarded as there is no basis for uniformity in pattern of governance; rather, 'diversity in governance' should be emphasized, as no two communities are ever the same (Akinola, 2006). What should be paramount is not uniformity but good governance that yields to the yearning and aspiration of the people.

\section{Conclusion and Recommendation}

Having discovered that the governments (federal, state and local) could not provide basic infrastructural amenities for the people, there is therefore, a need to find an alternative way of providing these basic facilities. There is need for the people to go back to the 'roots' from where they have 'departed', where people mutually cooperate to develop their community through self-help. Therefore, it is recommended that there must be a harmonious link 
between the leaders and the led. That is, it is necessary to establish effective mutual relations between the government and the people in order to allow development in the area of social services delivery.

\section{References}

Akinola S. R. (2006). "Structural Transformation and Polycentric Governance: A Constitutional Gateway towards Nigerian Democratization". Paper presented at a Working Conference on "Designing Constitutional Arrangements for Democratic Governance in Africa: Challenges and Possibilities. Organised by the Workshop in Political Theory and Policy Analysis, African Studies Program, and Office of International Programs, Indiana University, Bloomington, USA, 30-31 March, 2006.

Akinola, S. R. (1992). Governance and the deprived group: A Case from Oil Producing Region of Nigeria. Journal of Nigerian Public Administration and Management, Vol. 2(2.). pp. 68-77.

Akinola, S. R. (2007). Coping with Infrastructure Deprivation through Collective Action Among Rural People in Nigeria. Nordic Journal of African Studies Vol. 16(1).pp 30-46.

Akinwale, A. A. (2010). The Menace of Inadequate Infrastructure in Nigeria. African Journal of Science, Technology, Innovation and Development, Vol. 2, No. 3, pp. 207-228.

Anazodo, R., Okoye J. C. and Ezenwile, U. (2012). Leadership-Corruption: The Bane of Nigeria Development. African Journal of Social Sciences, Vol. 2, No. 3, pp. 124-134.

Ayo, B. S. (1988) "Social Policy", in V. Ayeni and S. Kayode (eds.), Nigeria's Second Republic: Presidentialism, Politics and Administration in a Developing State, Lagos: Daily Times Publication.

Cohen, B. (2003). "Urban Growth in Developing Countries: A Review of Current Trends and a Caution Regarding Existing Forecasts”. Elsevier Ltd, Great Britain.

Department for International Development (DFID) (2002). Decentralisation and Governance: Policy, Planning and Implementation. Netherlands: Ministry of Foreign Affairs, Directorate for International Cooperation (DGIS) DMV/VG, Peace Building and Good Governance Division.

Eziyi, O. I. (2009). Community-led infrastructure provision in low-income urban communities in developing countries: A study on Ohafia, Nigeria. Elsevier Journal Cities 26, pp. $125-132$.

Federal Government of Nigeria (2007). Service Compact with all Nigerians. Abuja: Servicom.

Makinde, M. A. (2002). Awo as a Philosopher. Ile-Ife: Obafemi Awolowo University Press Ltd.

Mukoro, A. (2009). Building Instituttions for Partnership in Local Governance in Nigeria. International NGO Journal Vol. 4(5). pp. 216-224. 


\section{MInstitute Macrothink $_{\text {Int }}$}

Journal of Public Administration and Governance ISSN 2161-7104

Njoh, A. J. (2006). Tradition, Culture and Development in Africa: Historical Lessons for Modern Development Planning. Florida: Ashgate Publishing, Ltd.

Nnamani, D. O. and Chilaka, F. C. (2012). Economic Reforms and Social Service Delivery in Nigeria 1999-2007: Issues and Options. Arabian Journal of Business and Management Review (OMAN Chapter) Vol. 2, No.4, pp. 9-23.

Oguzor, N. S. (2011). A spatial Analysis of Infrastructures and Social Services in Rural Nigeria: Implications for Public Policy. GeoTropico, 5 (1), Articulo 2, pp. 25-38.

Okotoni, M. O. and Akinola, S. R. (1996). Governance of Nigeria's Villages and Cities: Case Studies of Ifetedo and Olode Communities. African Journal of Institution and Development (AJID) Vol. 2(1). pp. 70-81.

Okotoni, O. (2005). Local Governance and Poverty Alleviation: the Nigerian Experience. Paper presented at the Workshop on Local Governance and Poverty Alleviation: Lessons of Experience (Organised by African Development Bank (AFDB) and the Joint African Institute (JAI) in collaboration with KFW Entwicklungbank (German Development Bank), Tunis, Tunisia, June 21-24, 2005.

Olowu, D. and Erero, J. (1997). "Governance of Nigeria's Villages and Cities through Indigenous Institutions" in Olowu, D. and Erero, J. (eds). Indigenous Governance System in Nigeria. Ile-Ife: Anchor Print Ltd. pp.1-19.

Olowu, D.,Wunsch, J. S. and Ayee, R. A. (2004) Local Governance in Africa: The Challenges of Democratic Decentralization, Boulder, Colorado: Lynne Rienner Publishers.

Ostrom, E. (1990). Governing the Commons: The Evolution of Institutions for Collective Action. New York: Cambridge University Press.

Oyedele, O. A. (2012). The Challenges of Infrastructure Development in Democratic Governance. Construction Economics and Management I, 6119, FIG Working Week 2012. Knowing to Manage the Territory, Protect the Environment, Evaluate the Cultural Heritage. Rome, Italy, 6-10 May 2012.

Popoola, F. (2011). Governance Crisis in Nigeria: An Empirical Analysis of Co-Production as Panacea for Service Delivery. International Journal of Business and Social Science Vol. 2(16). pp. 211-218.

Rodney, W. (1972). How Europe Under-developed Africa. London: Bogle-l'ouverture Publications

Tulchin, J. S. and Ayee, J. R. A. (2004). Decentralisation and Democratic Governance in Latin America. Woodrow Wilson Centre Report on the Americas \#12 Woodrow Wilson International Centre for Scholars.

Wunsch, J. and Olowu, D. (eds.) (1990). The Failure of the Centralized State: Institutions and Self-Governance in Africa. Westview Press: Boulder, CO. 